\title{
Strategic Marketing Revisited after September 11
}

\author{
Jean-Jacques Lambin ${ }^{*}$
}

\begin{abstract}
Within the globalised economy, strategic marketing remains the best mechanism to adjust demand to supply, but it also triggers a virtuous circle of economic and social development, reinforced today by the social, cultural and technological changes observed in the market.

These evolutions in the interconnected global economy create grounds for optimism in that they are contributing to a more democratic and transparent market economy, based on new values.

In this new environment, national and supranational authorities have a key role to play: to monitor and to control the initiatives taken to meet emerging needs in order to reconcile market efficiency with the imperatives of a social vision.
\end{abstract}

Keywords: Strategic Marketing; September 11; Globalisation; World Economy; Competitive Interdependence; Civil Society's Power; Global Governance

\section{Introduction}

In the $21^{\text {st }}$ century, three major evolutionary changes have and will have a profound impact on the functioning of markets: (a) the globalisation of the world economy, (b) the integration of electronic commerce into our professional and private lives and (c) the emergence of new values promoting a market economy model aimed at sustainable development. These three evolutionary changes are not really new. But the disruptive events of 2000-2002 have dramatically highlighted their strategic impact.

By disruptive event, I mean facts - sometimes dramatic - that generate discontinuities in the prevailing perceptions and beliefs about society's organisation and values, thereby deeply modifying mentalities and behaviours, in such way that these will never be again what they used to be before the disruptive event.

The influence of these disruptive events cannot be properly assessed without reference to the development of the New Technologies of Communication and Information (NTCI) which, in just few years, have completely modified

* Full Professor of Market-Driven Management, University of Milan-Bicocca (jeanjacques.lambin@unimib.it) 
communication and interaction methods by creating, at the planet level, a higher degree of interdependence among economic actors and a dramatic amplification effect of disruptive events. As a result of this communication revolution, the world society - and the world economy - is now an inter-connected global society in which the players (suppliers, consumers, citizens, buyers, distributors etc.) are no longer abstract entities, but millions of individuals who speak and who are heard, and who participate in millions of 'one-to-one' relationships. This communication revolution reinforces the transparency and the democratic nature of world society and it is within this framework that the importance of the following five disruptive events must be analysed.

1. The September 11 attack on the twin towers of the World Trade Centre in New York, which dramatically demonstrated to the world public opinion the impact of globalisation: 'any where, at any time, by any one' What was perceived until then, as being a mere virtuality has brutally become a reality in everyone's mind. Since then, the issue of safety is a major obsessive issue and a priority concerning every facet of human activity in a world that is becoming indeed a global village.

2. The accounting and financial scandals in the US of Enron and WorldCom (among many others), which have questioned the professionalism of American management - until then always presented as a reference model and which have brought discredit on the role of financial audit firms and on the prevailing corporate governance rules and practice. More fundamentally, these events have contributed to erode in the public's opinion the capital of trust in today's capitalism. One must add that Europe was not immune to this crisis, as illustrated by the case of the Flemish company Lernaut \& Hauspie, the French Vivendi and more recently the Dutch Ahold, to mention just a few. As a result of this crisis, a fundamental review of the rules of corporate governance is taking place, with a lively debate in various quarters on corporate social responsibility (CSR) and, on a more technical ground, the move in the European Union to International Financial Reporting Standards (IFRS) to increase the credibility of financial reporting.

3. The crash of the speculative stock market in 2001 and, in particular, the collapse of the internet start-ups in the so-called New Economy, which was largely due to an excessive faith, among those new entrepreneurs, in the power of communication and selling combined with a lack of longer term strategic vision. It is surprising to learn that most of these new entrepreneurs originated from the consultancy world and many held a management degree. As a consequence, there has been a renewed interest in many business schools for training programmes in entrepreneurship, traditional programmes in management placing in fact more emphasis on managerial issues of existing companies. The concept of an entrepreneurial economy is gaining ground over the concept of a managed economy.

4. The popular success of the alter-globalisation movement which, despite the riots that it, unfortunately, still generates, has become a voice that is listened to and increasingly heard, in particular in the Porto Alegre forum, the social replica of the Davos economic forum. The discontinuity here is the irruption of civil society's voice into the economic and financial debate, which is not longer confined in business or political quarters, but which is made public. 
5. Finally, the recent evolution of US-Europe relationships, whose impact is hard to assess at this stage, but which raises a question: are we observing the beginning of the end of the traditional Atlanticism and the emergence of a competition 'USA versus the rest of the world', taking the form of 'committed consumption' guided by political opinions? In other words, could politics guide purchasing behaviour? Some leading indicators of 'politically correct' consumption have already been observed: Are they revealing deep changes or are they simply reflecting short-term sensitivities?

These five disruptive events have important managerial implications, and in particular on strategic marketing. The objective of this paper is to review these implications in organising the discussion around the three following themes: the globalisation of the economy, the new technologies of communication and information and the emergence of new values.

\section{The Globalisation of the World Economy}

The end of the 1990s is characterised by the completion of the process of internationalisation of the world economy through globalisation. By globalisation, we mean:

'The set of processes which contribute to the elimination of regional barriers and facilitate the flow of capital, goods and information at the planet level, and the realisation that the world functions as an integrated whole'.

Thus globalisation also implies the dissemination through the media of new norms and values, which oblige companies to revise their international strategy.

\subsection{The Growing Competitive Interdependence}

One of the most important effects of globalisation is the interdependence it creates between markets. National markets cannot be viewed as separate entities any more, but rather as belonging to a regional or world reference market. What happens in one market directly influences others. Here are three examples.

$\square$ - The relatively minor pollution problems of Coca Cola in Belgium and in France in 1999 triggered a health scare that spread rapidly to other European nations, which hit the Coca Cola share price on the New York stock market. Many commentators cited the crisis at the time as one of the contributory factors to the Coca Cola CEO's surprise early retirement.

- In few months, the SARS epidemic has contaminated 30 countries over the world.

- Similarly the Iraq war, in reality a very local war, has paralysed the world economy. 
An economy that is highly integrated in the world network, becomes more vulnerable to external shocks such as a devaluation, a sudden rise in the oil price, a financial crisis or a war threat. This evolution has several managerial implications.

1. The traditional multi-domestic (or multinational) organisation forms become obsolete and are replaced by trans-national organisations covering a region or the entire world. The problem is to maintain a good balance between the flexibility and formalisation of behavioural rules, the standardisation or adaptation of products and brands, and the centralisation or delegation of decisions. What is clear today is that many firms are revisiting the full standardisation rule 'one size fits all'.

2. Mergers and Acquisitions are necessary to reach the critical size required to compete in an enlarged market. (Daimler-Chrysler, AOL-Time Warner, Carrefour-Promodés, ING-BBL), a strategic move which is far from being complete in Europe, in particular in view of the recent enlargement of the EU to 25 countries.

3. Standardisation of brands and of communication strategies are motivated by the necessity to achieve economies of scale, to remain competitive in the enlarged market.

This is the reason why, in 1999, the Unilever Company decided to concentrate its activities on 400 international brands and to eliminate 1200 brands or $75 \%$ of its brand portfolio.

For the international firm, it is always difficult to maintain a good balance between the two conflicting objectives, standardisation - which is supply-driven and adaptation - which is market-driven The problem is to know how far to go in the standardisation track, the risk being to lose contact with the local market simply to reduce costs.

A recent study of 500 brands from the food sector covering four European countries (France, Italy, United Kingdom and Germany) has shown that local brands enjoyed a level of awareness higher than international brands and a stronger brand image on several attributes and in particular on the criterion of trust (Schuiling, 2002).

$\square$ The CEO of the Coca Cola company, the undisputed leader of brand globalisation, has acknowledged that a too strong standardisation strategy damage the brand image. The CEO has invited the local country marketing teams to adapt locally the Coca Cola brand strategy and even to introduce new local brands.

In Belgium, Procter \& Gamble a strong supporter of global marketing, has unsuccessfully tried to weaken the local brand Dash, by stopping all advertising during more than 9 months, in order to push its international brand Ariel, only number 2 in the detergent market.

This issue is particularly topical in Europe since the launching of the euro, the new European currency, which by facilitating price comparisons between 
countries, reveals substantial price disparities, which stimulate parallel imports with an alignment to the lowest current level of price.

This new competitive interdependence affects every company in their domestic market and in the international market and obliges them to re-evaluate their competitive advantage, taking as benchmark the strongest competitor in the enlarged reference market. Thus, in this new competitive environment, it is not enough to be customer-oriented. The firm must also become competitor-oriented. Competitors' orientation includes all activities involved in acquiring and disseminating information about competitors in the target market and requires an explicit account of competitors position and behaviour in strategy definition,

\subsection{The Growing Power of Large International Distributors}

A significant change of the last ten years, in Europe and in the United States as well, is the growing power of the retailers. From passive intermediaries in the channel, retailers are now active marketers developing new store concepts and own-labels brands designed for well-targeted segments. They are now directly competing with manufacturers' brands; they have the power to dictate terms to their suppliers and to push their brands off the shelves if they are not leaders in their product category. Several factors explain this shift of power from manufacturers to retailers.

1. The high concentration rate of retailers, specifically in the fast moving consumer goods (FMCG) sector: in 12 European countries, the top three retailers account for $50 \%$ of the market.

2. The adoption by retailers of sophisticated store brand policies targeted to segments often neglected by manufacturers (the low end of the market) and the growth of private labels, with market share as high as $42 \%$ in Switzerland, $30 \%$ in Great Britain and higher than $15 \%$ in six other European countries.

3. Several retailers are adopting rapid internationalisation strategies, like Wal-Mart in Germany and the UK, Carrefour-Promodès in Latin America and Japan, Delhaize in Eastern Europe, US and Asia, Ikea in the world and most recently in Russia and Malaysia, the Dutch Ahold, the German Albrecht, etc.

4. The emergence of new breed of retailers, the hard discounters, who in warehouse stores, charge very low prices on their own private brands while excluding suppliers' brands from their shelves.

The result has been to deeply transform consumer markets and to modify the balance of power between manufacturers and retailers. Today powerful brands like Coca Cola and Nestlé need large retailers and retailers need them, even if the development of e-commerce creates new opportunities for manufacturers who could strike back and bypass traditional intermediaries.

Vertical competition reduces the market power of large international brands, facilitates adaptation to local needs and stimulates price competition, as evidenced by the success of private labels.

In consumer markets, retailers are today irreplaceable actors actively and constructively participating in the globalisation process. In these markets, being 
consumer-driven is not enough. The firm must become distributor-driven to avoid the risk of being de-listed and should design retailer-driven $B 2 B$ marketing programme based on in-depth understanding of their generic needs, such as a desired store image, efficient order fulfilment, protection from undue competition, etc.

\subsection{The Emergence of Transnational Market Segments}

In the Triad countries, one observes the existence of trans-national segments, i.e. groups of consumers present in each country and having the same needs and expectations. Thus globalisation need not mean standardisation of life styles across countries. In the world today, in parallel with the globalisation of the economy, there has been an explosion of identity crises among nations, regions, religions, ethnic and linguistic groups having the desire to maintain and to claim their cultural difference. So globalisation does not mean uniformity.

The fact that one dominant country tends today, consciously or not, to impose its culture, its language, its life styles can create the illusion of uniformity. But behind a superficial layer of uniformity created by a few popular brands (always the same: Disney, Hollywood, McDonald, Coca-Cola, Marlboro, CNN...) are hidden important cultural, religious, racial and linguistic differences.

We are confronted with a paradox. The interdependence of markets referred to above, combined with this cultural fragmentation, results in a cultural convergence, thereby creating trans-national market segments, i.e. groups of consumers present in each country and having the same needs and expectations. Thus globalisation need not mean standardisation of life styles across countries. It simply means that, across countries, there are groups of consumers with the same profiles that can be approached with the same brands and communication campaigns.

$\square$ It is still difficult today to refer to a European consumer, even if one observes a growing convergence in life styles and in consuming habits within the European Union. By contrast, there are numerous transnational segments such as executives of international companies, students in management, sport professionals, high-fashion conscious women, etc.

The affirmation of the individual and the identity crisis forces companies to adopt a mass-customisation strategy whereby goods and services are individually customised in high volumes but at relatively low cost. Flexible manufacturing and electronic commerce make possible today this mass customisation approach.

\subsection{The Impact of Disruptive Technological Innovations}

On the technology front, and in parallel with globalisation, one observes a convergence of markets triggered by disruptive technological innovations, which upset traditional market boundaries and change the traditional definition of an industry. 
Digitalisation for example eliminates boundaries between printing, photography, television and image processing systems. Convergence is also observed in information technology, telecommunication, banking and insurance, office automation, etc.

By disruptive innovations, we mean a new way of playing the competitive game that is both different and in conflict with the traditional way adopted by established leaders (Charitou and Markidès 2003).

Examples include Internet banking, direct insurance, low-cost airlines, home book retailing, etc. (Charitou and Markidès 2003).

As a result, established leaders in a variety of industries were asking the same question: Should we respond to these disruptive innovations, with the risk of damaging our core business?

Convergence leads companies to define their reference market in terms of generic needs instead of technologies and products, since technologies are fast changing whilst generic needs are stable. As a result, many firms tend to view themselves as a service firm, where the physical product is secondary but where the company mission is to propose to the client a solution-to-a-problem and not simply a product.

It is the case, for instance, of the company Automatic Systems initially a manufacturer of metallic gates and doors, selling now 'access control systems'; of Nestlé who in addition to selling the Nescafé brand, is selling the Nespresso system; of IBM who is selling 'computerised solutions to managerial problems'; of Microsoft selling the Office system; of Starbucks who organises the distribution of its products in a franchised network of coffee shops, etc.

The fast development of technology also has a strong impact on innovation strategies. A distinction is often made between a market-pull innovation, i.e. one that directly meet observed needs, and a technology or company-push innovation, i.e. one that results from research, creativity and technological opportunities.

1. In the first case of market-pull innovation, needs are expressed and articulated. The objective is to find wants and to fill them. Primary demand is latent and the task is to develop and stimulate this latent demand through operational marketing. This is response strategic marketing, the traditional role of strategic marketing, which still prevail in developing and growing economies.

2. In the second situation of company-push innovations, the products or services proposed are often ahead of expressed market needs. With so-called discontinuous or disruptive innovations, the market boundaries are not well defined, needs are not articulated, the competitive environment is blurred and often the innovation upset existing market practices and habits. Thus the key question is to know whether there is a need in the market for the company-push innovation. 
In highly industrialised countries, it is the second situation - leading to creative strategic marketing - which tends to prevail and to generate most growth opportunities. The role of operational marketing is more complex and risky here, since primary demand must be created.

The characteristics of high-technology industries have implications for the new product development process, namely speed and flexibility in product development, close co-operation with customers and systematic monitoring of the technological environment. Thus, in high-technology markets, strategic marketing has a crucial role to play, particularly in organising cross-functional structure, namely the 'R\&D-Production-Marketing' interface to disseminate the market orientation culture throughout the entire organisation.

\subsection{The Affirmation of Civil Society's Power}

In the industrialised world, being better educated and exposed to the consumerist culture, consumers represent a force of responsible citizens that firms and public authorities can no longer ignore. Six attitudes characterise the new consumer:

1. A feeling of power. Consumers behave in markets where supply is plentiful, brands proliferate, competition for consumer's loyalty is intense and information sources numerous.

2. A professional purchasing behavior. Well-educated and experienced, consumers are smart shoppers, able to make trade off between brands, stores, advertising and the recommendations of sales people. They become increasingly discriminating in their demand for customised services and want complete information about their purchases. From passive consumers, they become more active or 'consum'actors'.

3. The satisfaction-delight-loyalty relationship. The new consumer holds the firm responsible in case of dissatisfaction. Thus a dissatisfied customer is a lost customer, a damaging effect in zero-growth markets, where replacing a lost customer by a new one is particularly difficult and costly. Moreover, research results show that simply giving what is expected is not enough to keep a customer loyal. The objective should be to give more than expected, to have delighted customers.

4. A search for new values. In industrialised countries, economic prosperity and mass consumption have lifted the aspirations of consumers from materialistic needs to the search for new values: Initially looking mainly for comfort and safety, they are more and more looking for stimulation, pleasure, change, innovation, surprise.

5. A need for a dialogue. Consumers are represented by powerful and vocal consumerist and by non-governmental organisations (NGOs). Just as significant is the growing influence of environmental groups, human rights activists, labour and religious groups and a host of other organisations who collectively make up 'civil society'.

6. In addition, consumers want an ethical consumption and do not want to have guilty feelings from their purchases nor from the advertising associated with their brands. Buying and using products and brands having acceptable price and quality ratios, YES. But also brands meeting ethical criteria such as the 
product greenness, the social and human practice of the firm, its political and strategic commitments, etc.

This emerging trend toward ethical consumption is confirmed in France by survey results published in October 2002 by the French consortium 'L'éthique sur l'étiquette' (www.ethique-sur-etiquette.org):

$90 \%$ of the persons surveyed would to prefer to buy products from companies respectful everywhere of the workers social right.

$76 \%$ say that they are ready to pay a premium price for a product imported from a poor country if they are sure that the local workers are decently remunerated.

A more recent evolution is the so-called 'politically correct consumption' (or the committed consumption), which designates a purchasing behaviour in which the consumer is more involved by considering that a brand purchase is similar to a political act. To select a brand or a company is comparable to a political vote: one selects a candidate in whom we trust. Similarly, in the market place one can make politically correct purchase decisions.

$\square$ A case in point is the Mecca-Cola brand recently launched in the French market and targeting the Muslim community. Its slogan is: 'Do not drink stupid, drink committed' (Ne buvez plus idiot, buvez engagé). The brand also promises to give 10\% of its net profit to Palestinians charities (info@mecca-cola.com).

Since the beginning of the Irak war, boycott calls proliferate on the web, either from Arab countries suggesting the boycott of American products or from American sites inviting in particular to the boycott of French products.

By way of an example, the American site www.howtobuyamerican.com published a list of 450 French (and other) brands, indicating the American substitute product or brand that should be preferred. Similarly, an Arab site gives a list of American products to boycott in quoting their prices in the number of war bullets that Israel could purchase (a Coca-Cola $=7$ bullets, a pizza $=140$, etc.)

It is hard to assess the real impact of systematic boycott targeting consumer products such as Coca-Cola, Pizza Hut, Pepsi, McDonald, Starbucks, Estée Lauder, all products having local equivalents. Since September 11, it is Saudi Arabia that has suffered most from the boycott with a drop of $43 \%$ of American exports during the first quarter of 2002 (Reuters, June 2002). In France, wine exports to the USA have declined by $21 \%$ during the first four months of 2003 , a decline too high to be attributed to the sole rise of the euro to the dollar.

This growing power of citizens generates new expectations which directly contribute to improving the functioning and transparency of the market: liberty of choice, better information, pressure on prices, product safety, after-sales responsibility of the manufacturers and ecologically friendly products. It also 
constitutes a strong countervailing power to the power of companies and even to the power of public authorities. New and more responsible relationships between consumers and the industrial world are developing which challenge the stereotype of a manipulated and defenceless consumer.

In short, globalisation of the world economy increases the complexity of markets: competition intensifies, new actors become powerful players, consumers are more vocal and demanding and technological innovations are changing the configurations of traditional markets. Arguably this increased market complexity creates huge difficulties for the firm and requires a greater understanding of the global environment and a more finely tuned strategic analysis of market behaviour.

A recent study published by the American consultant Bain (Root and Smith, 2003) covering a sample of 729 international companies from 7 countries (France, Germany, Italy, United Kingdom, Japan, Australia and the United States) having a sales revenue larger than $\$ 500$ million, has shown that only 124 companies (or 1 out of 6) have succeeded during the years 1996-2000 to achieve a profitable growth strategy of at least $8 \%$ (i.e. the GNP growth plus the inflation effect).

This observation illustrates the fact that to be an international successful player in a globalised market is far from being an easy game.

\section{The New Technologies of Communication and Information}

The crisis in the New Economy and the collapse of the Internet start-ups in the Nasdaq are still present in everybody's memory. The causes of these failures are known today:

1. too fast international development and under-estimation of the time required reaching the break-even point;

2. a lot of good ideas but rapidly imitated due to the lack of entry barriers and the absence of strong brands;

3. absence of value proposals sufficiently differentiated from the bricks-andmortars retailers;

4. misunderstanding of the consumer behaviour on the web more interested in browsing than in buying;

5. priority given to sales and communication and not to delivery.

Despite its growth crisis, the New Information and Communication Technologies (NICT) have grown exponentially during the last five years, but the speed of change has often confused companies, provoking widespread questioning and reassessment of the way markets are likely to be organised and marketing strategy developed in the future.

\subsection{A New Generation of Electronic Commerce}

In fact, we are entering in a second generation of electronic commerce: By electronic commerce (EC), we mean, 
'Any electronic exchange which contributes to the commercial and marketing activities of the firm and which facilitates relationships between customers, suppliers and/or any other partners'.

Too often EC is merely perceived as a narrow selling instrument deployed through a web site - little more than a banner presenting the company and a catalogue of products from which customers can order directly online. The reality is that very few firms (particularly SMEs) have so far been able to sell to their endcustomers through the web. By contrast, however, many have adopted Electronic Data Interchange (EDI) systems, which hook together computers of commercial partners via telephone lines. Once established, this connection facilitates and accelerates communication within the supply chain for ordering between suppliers, distributors and customers, for disseminating information and thereby generating substantial cost savings.

$\square$ In addition to selling on line and to EDI, other EC applications include an extranet to reinforce links with traditional commercial partners (wholesalers, importers, retailers), multimedia kiosks at the points of sale to present a catalogue, or a system of personalised electronic messages to maintain continuous relationships.

The main characteristics of electronic commerce are well known.

$\square$ Virtual ubiquity of demand and supply - easy access to quality information by a large public any where, any time - world-wide comparison of offerings and prices - absence of entry barriers separation between production and selling - equal opportunities for each seller, etc.

These characteristics of EC are improving the efficiency of markets. We are close to a situation of pure (or perfect) competition, where the tools of strategic marketing (differentiation, innovation, loyalty,) are to some extent neutralised. In this context, the objective of value creation for the client becomes more difficult to achieve given the limited potential for differentiation and the absence of protection of new ideas.

In this new environment, the firm controlling the delivery to the market has a major competitive advantage. In traditional business structures, selling is seen and organised as a servant to production. In e-commerce, instead of selling what it makes, the virtual company will sell what it can deliver, no matter who makes the products. The contact with the market and the savoir-faire in terms of physical distribution and logistics become the core competence (Drucker, 2000).

\subsection{The Concept of Meta-Market}

One of the main causes of failure of the start-ups in the New Economy was the lack of sufficiently differentiated proposals by comparison with the proposals made by the physical stores. Online applications should not systematically replace traditional activities. The challenge is to redesign the traditional proposal by 
presenting a more global offering or a new combination of traditional offerings thereby giving more value to the client.

For example a real-estate agency going online can provide information not only on available apartments or houses, but also on house renovation, home insurance, house equipment, or removal services, selecting the assortment of services by reference to the set of needs of the client in search of a shelter.

Added value analysis based on what is called the meta-market concept (Sawhney, 1997) leads to an offering or to an assortment of offerings defined by reference to all the elements (activities and services), which comprise the cognitive space of the client. While in general market are organised around products and services, the consumer purchasing process is structured by references to activities that are linked in cognitive space.

$\square$ For example, on the supply side the car market is organised around car manufacturers, car dealers, car insurance brokers, financing services, garage and maintenance services, mechanics, etc. By contrast, the cognitive space of a car purchaser is composed of information search, evaluation, price negotiation, purchasing decision, insurance, financing maintenance and eventually resale's value.

The web firm has the possibility to match the supply market concept based on the products with the meta-market concept based on the logic and the perceptions of the consumer. Thus, the meta-market concept gives to the virtual firm the opportunity to fully implement the customer-orientation concept. In this way the web firm can position itself and its network as a new intermediary between the customer and market actors, thereby upsetting traditional sectors and creating competition stretching across conventional market boundaries.

\subsection{The Reconfiguration of Distribution Networks}

Once the potential EC applications are identified, it is useful to verify whether each online application 'complements' or 'replaces' off-line operations. Online applications do not systematically replace traditional activities. In many cases, the best solution is a combination of the two, thereby promoting complementarities (the 'click-\&-mortar' concept). A classic mistake is to do online only what is done manually off-line, simply to generate costs reductions. The firm's marketing strategy should dictate policy in this case.

$\square$ This mixed strategy is the one adopted by Barnes \&Noble, Toy-RUs, Virgin-Express, by contrast with Amazon.com, Dell-Computer and Ryan-air, which operate online only.

A second strategic issue raised by $\mathrm{EC}$ is the reconfiguration of the distributive network. A commonly held view is that EC will enable companies to deal directly with the end-customer, leapfrogging an existing distribution network and thereby reducing transaction costs. Why remunerate middlemen, the thinking goes, if one 
can communicate directly with the customer through an electronic link, giving her or him the possibility to place an order directly at lower cost? This is called disintermediation.

In reality, the challenge is far greater. Taken separately, the cost of the direct contact is indeed lower, but managers need to view the total cost of the transaction. In many situations, the reduced cost of the person-to-person relationship can be offset by substantially increased logistics costs. The issue is not one of sidelining distributors, rather of redistributing the tasks and functions among the existing actors in the chain. This redistribution (or re-allocation) of tasks is particularly relevant for product information, advice to customers, after-sales services, physical delivery, product and service bundling and product demonstrations or trials. Several options exist:

1. to place on the company's web site - little more than a banner presenting the company and a catalogue of products without price list. The distributors then perceive the site as a promotional support;

2. charge on the web site the same price than the market price but add delivery costs, which keep attractive the traditional distributor's offering;

3. sell on the web side but return a commission to the distributors located in the geographic zone where the product is sold;

4. adopt the same pricing strategy than the distributors, which is an aggressive strategy creating direct competition vis-à-vis the distributors.

Thus, the issue is more a question of re-allocation of the distribution tasks among the different actors.

It would be possible therefore for a firm to deal directly with the end-customer where the provision of up-to-date information is at stake, while leaving to intermediaries those tasks requiring physical proximity (Dimitriadis and others, 2003).

\subsection{The Role of Infomediaries}

Where disintermediation takes place, the absence of physical contact between the seller and the buyer creates a new need among consumers, the need for assistance in collecting and processing information. In traditional markets, and in particular in B2C markets, the seller has more information than the buyer: information on costs, levels of quality, product availability, and prices of competing or substitute products. Different levels of middlemen (wholesalers, retailers, agents,) were there to disseminate this information along the distribution chain. The elimination of these filters transfer the responsibility of the search and of the selection costs directly to the consumer who is confronted with a problem of information overload (Berquier-Ghérold, 2000).

In markets driven by EC, a new breed of intermediaries - the infomediaries - is emerging and assumes the management of information on behalf of the consumer. Web sites regrouping buyers and organising auctions are a case in point. As a result, market transparency increases and the negotiation advantage switches to the buyer. By contrast with traditional intermediaries who typically relay the manufacturer's message and share its profit margin, these new networks of middlemen reverse the communication flow through systematic use of tenders. 
$\square$ As a travel agency designs and proposes a package tour combining a large variety of services (transportation, hotels, guided tours, entertainment) the infomediary plays the role of an authorised agent or of a broker proposing a search engine, a selection procedure of products and services and even price negotiation, while keeping its total independence vis-à-vis the suppliers.

The success factor for the infomediary is customer trust. This new type of middleman can solve four problems for the consumer: (a) to reduce the costs of collecting information, (b) to provide relevant and unbiased information, (c) to certify the reliability and quality of the suppliers, (d) to facilitate transactions.

\subsection{The Geographic Market Coverage}

Adopting EC technology does not necessarily imply that companies should suddenly start operating on a global stage. If EC facilitates communication, international physical delivery and logistics still require specific competence and significant financial resources. Thus, decisions concerning market coverage should be taken only after considering the physical (delivery) and psychological (communication) implications.

The spectacular development of the NICTs and the resulting globalisation of the world market can give the illusion that distance does not matter anymore. In reality, distance is a multi-dimensional concept and a distinction must be made between the four dimensions of distance (Ghemawat, 2001): geographic (physical remoteness), administrative (preferential trading agreements), economic (wealth differences) and cultural (linguistic ties). The NICTs have eliminated only one component of geographic distance: the communication link.

\subsection{The Impact of Electronic Communication}

The development of electronic communication not only modifies the respective roles of personal selling and of advertising, but also changes the objectives and the content of advertising communication. The characteristics of electronic communication are well known.

Interactive communication - advertising on demand - more informative and factual communication - a personalised electronic mail system - an egalitarian medium - a world wide communication any where any time.

The most important impact of electronic communication has been to reduce dramatically interaction costs, that is the administrative costs borne to get people to work together, to collect information, to co-ordinate activities and to exchange goods and services. According to a McKinsey report, these costs amount to 55 per cent of the total administrative costs of companies operating in advanced economies. The reduction of telecommunication and transport costs, with its massive diffusion of ever cheaper and more powerful information, progressively eliminates barriers between markets and gives access to the international market to any individual having talent or ideas. 


\subsection{The Issue of Private Life Protection}

The individualisation of online communication creates the need for personalised data to customise the offering. Therefore, any element of information susceptible to differentiate the potential customer and to draw its detailed profile is gaining a commercial value. This explains the development of personal data banks and by way of consequence the highly sensitive issue of privacy and of private life protection on the Internet.

The objective of the European Data Privacy Directive issued by the EU in 1995 protects all personal data and allows its collection for specific, explicit and identifiable purposes, but does not allow any further processing. Data collectors must inform the individual of the specific purpose for the recorded information and must keep the information accurate and up to date. Data subjects are guaranteed access to review personal information and they must be given the right to refuse to have their personal data transferred to a third party. In addition, if data are collected for one purpose and is later used for another, the data subject must be notified and given an opportunity to opt out of the second use (Gladstone and Scheibal, 2001).

Thus the days when companies could do pretty much as they pleased over privacy are disappearing. Pressure from governments and customers to comply with new rules is intensifying. This EU Data Privacy Directive is a first manifestation of a form of world governance.

In short, electronic commerce provides to the firm new opportunities for dealing with the market in a more efficient manner, not only in terms of costs savings but also in terms of greater customisation of the firm's offering and of its communication and selling strategy. EC has a strong impact on operational marketing and is also a major challenge for strategic marketing.

\section{The Emergence of New Values}

Our era is characterised by a number of paradoxes (de Woot, 2002).

1. Our capacity to produce wealth has never been greater while the inequalities in the world have never been larger. The extraordinary dynamism of the market economy exists alongside the near total poverty of half of humanity.

2. The economic tendency is towards globalisation while politics have remained mainly national in character. It's as if the technical and economic system had been left to its own devices.

3. The environment is deteriorating while scientific knowledge, technical know-how and accumulated wealth could safeguard the planet.

This situation that is the result of an extremely complex accumulation of factors affects companies and obliges them to rethink their responsibilities toward society and to consider the market economy in its environment together with its strengths but also its weaknesses and malfunctions. Today an increasing number of voices are being raised (European Commission, business leaders, NGOs, etc.) supporting the idea of sustainable development. 


\subsection{The Socio-Ecologic View of Consumption}

The environmental movement and the socio-ecological view of consumption reflect a new awareness of the scarcity of natural resources, the uncontrolled growth of waste and the social cost of consumption.

$\square$ Between 1890 and 1990, the world population has been multiplied by 4 , while consumption in industrial products was multiplied by 40 , energy use by 16, water consumption by 9, fish consumption by 35 and the total world production by 14. This discrepancy between population and consumption growth is even higher in highly industrialised countries.

This new awareness regarding the scarcity of resources reflects a changed attitude to consumption as something, which is no longer, viewed as an end in itself but which must take into account its upstream (opportunity cost) and downstream (repair and prevention cost) implications. Globalisation is positively disseminating this new culture as markets become more interdependent and as procurement and production activities spread across the planet.

The basic argument of the ecologist is to set a price on the use of the environment which was until recently regarded as a 'free good'.

$\square$ The economic instruments used to set a price to the use of the environment generally take the form of a direct tax on the polluting activities, either in a prevention (eco-taxes) or in a repairing perspective (eco-fees).

The life-cycle inventory model (LCI) is the basic tool used by the ecologist and through which a product's total environmental impact is evaluated from 'cradle to grave'.

Life cycle inventory (LCI) is a process that quantifies the use of energy, resources and emission to the environment associated with a product throughout its life cycle. It accounts for the environmental impact of raw materials procurement, manufacturing and production, packaging, distribution and in-use characteristics straight through to after-use and disposal (Lambin, 2000).

Faced with this thinking, firms are being forced to review their underlying product concepts in the light of everything from raw material procurement to afteruse and disposal. In future, the certification ISO-14001, which measures and certifies the degree of greenness, will probably become a pre-condition for being short-listed in international tenders, as it is already the case for the ISO-9000 norm.

A new EU directive currently under consideration by the European parliament is a good example of the practical implications of ecology.

Under its terms, vehicle makers will have to bear the expense of recycling their cars, buses and trucks. The directive encourages the use of recycled material. It requires 85 per cent of the weight of all vehicles 
sold in the EU after 2007 to be made from reclaimed substances. This directive will be in application retroactively as soon as 2006, which means that the European automobile industry will have to recycle 170 millions cars currently in use in Europe.

The environmental concern behind this directive comes from the market and is the expression of new needs within society. It is not a fad or a protest trend. It is a way of life, which has and will spread rapidly throughout all levels of society and throughout the world. This preponderance of collective over individual needs is a new economic phenomenon and represents a check to the wilder forms of capitalism.

Until recently, such environmental consciousness could be viewed as a preoccupation of industrialised economies, but the interdependence of markets that comes with globalisation has changed this. It also explains why new environmental norms are at the core of the ongoing international trade negotiations, although the EU's attempts to impose higher standards are often seen by the US as an obstacle to free trade and by developing countries as a form of disguised protectionism.

\subsection{The Objective of Eco-Efficiency}

The socio-ecologic view of consumption induces firms to improve their 'ecoefficiency', that is to increase the volume of production per unit of natural resource. This objective will be reached by applying to the use of natural resources the principle adopted by Henri Ford during in the years 1920 in the use of human resources: 'to do more with less'.

Historically, labour productivity has increased by a factor 200 in industry and by a factor 20 in agriculture. This means that, in industry, one worker do the job where 200 workers were required three centuries ago. By comparison the productivity in the use of natural resources and energy per production unit, has increased by a factor 10 only since the eighteen century. Nevertheless, this productivity gain makes possible today to produce one ton of steel with 10 times less energy than before (E. Lambin)

All specialists agree: the potential for improving the eco-efficiency of most products is enormous (through de-carbonisation, de-materialisation, reduction of waste and pollution, etc.). Beneficial for the environment, improving the ecoefficiency also improves the firms profitability thereby creating a win-win situation, where gains are achieved both on the environmental and economic sides.

Last but not least, the image of the firm having a good ecological reputation is becoming a stronger argument for creating loyalty among customers, employees and shareholders. Today, more investors are expressing their preferences for ethical funds regrouping firms having good social and ecological credentials, as illustrated by the growth of sustainable investments funds.

\subsection{Towards a Global Governance}

The globalisation of the world economy raises the issue of the role of the State and of global governance. It is an established fact that national States are deprived 
from their national prerogatives to the extent that they do not control trans-national activities. The contrast between the means that the nations have at their disposal for national governance (between $30 \%$ and $50 \%$ of GNP) and the weakness of resources at the global level is striking. It is recognised that a market economy needs a strong governance to define and enforce the rules of the competitive game. It is up to the State for example to balance the main macro-economic issues (such as price stability) and to ensure a minimum social cohesiveness and solidarity. A market economy, be it national of global, needs a strong governance to function smoothly. In a market that is hardly regulated or not regulated at all, the risk to see wild capitalism prevailing is high.

$\square$ If the market economy system in Russia, did not work well during the first years of its adoption it was largely due, not to the market, but to a too weak government and to the absence of the market and economic regulations that are necessary to ensure a smooth functioning of a market economy. In this type of unregulated market, 'might is right' and the mafia or a bunch of corrupted individuals are running the show.

But in an under-regulated global market, which international organisation will assume this global governance? In other words, if there is a 'global village' which municipal board will be in charge?

In today's world, the urge to maintain and to claim one's own cultural identity is stronger than ever and, in the years to come, it will be the 'subsidiarity principle' that will guide decision-making. What can be best dealt with at a local level should be addressed locally.

For transnational issues on the other hand, like ecology, privacy on the web, safety, terrorism, health, etc., forms of world governance are necessary. A world government is hardly on the agenda but new forms of concerted global effort similar to the Kyoto, Montreal and The Hague conferences in the field of ecology, and to the Davos and Porto Alegre forums in the socio-economic field - can contribute to solutions.

Global capitalism needs strong countervailing powers, which go beyond the power of national governments. Contrary to the demands of the anti-globalisation supporters, the powers of supranational organisations like the WTO, the IMF and the World Bank should be reinforced and new supranational organisations created to deal with these trans-national issues. Without them the risk is increased that we end up with a much wilder form of capitalism than we have at the moment operating in a completely deregulated market.

\subsection{Corporate Social Responsibility}

Firms everywhere are embracing the concept of corporate social responsibility (CSR), and the financial corporate scandals in the US (Enron, Worldcom,) have contributed to reinforce this evolution. The reasons for the adoption of this business philosophy at the corporate level can be summarised as follows:

1. any firm needs a healthy and prosperous environment to reach its own development objectives. Economic progress cannot be built on a social disaster; 
2. a global economic system under which half of the humanity finds itself excluded is obviously not viable politically nor acceptable morally;

3. the welfare state and the social and fiscal solutions it implies have clearly reached its limits, both on qualitative and financial grounds;

4. rather than paying more taxes, civil society should wake up and commit itself, where it has the appropriate skills and resources.

The responsible corporation acknowledges that it has a responsibility towards society. It is an organisation, large or small, which wishes to establish a long-term and sustainable relationship with the community where it lives and from which it gains its prosperity. Participating in social life, the responsible corporation commits its resources and competence to help combat social problems, often in cooperation with public authorities. The domains where the responsible corporation can contribute are several and varied

$\square$ To develop the economic fabric of a region - to maintain or develop
employment - to participate in education programmes - to protect the
environment - to dialogue with stakeholders - to promote urban
development - to fight against social exclusion.

A key part of the vision is that corporations are the most powerful force for change in the modern world: state, church, and university should not shy away but their actions, slower by nature, merely complement the more important role of companies.

In the new global economy, ethical behaviour which consists of 'of doing well (financially) by doing good (socially)', is not only compatible with the objective of modern capitalism - as evidenced by the success of ethical funds - it represents a competitive advantage by meeting the market's demand. Again the interdependence of markets created by globalisation helps ensure that these new standards of behaviour become an imperative for any firm with the ambition to become a player in the global market.

This philosophy of responsible management is rapidly gaining acceptance in Europe in the business community, as evidenced by the proliferation of charters and codes of conduct, the growing adoption of the Triple Bottom Line (TBL) reporting systems, the charter of Human Responsibility suggested by the Alliance for a responsible world, the efforts of Transparency International, the anti-bribery convention of the OECD, etc. TBL is particularly important. The Triple Bottom Line represents the idea that businesses should account for their performance on economic, environmental and social criteria and attempt to satisfy their stakeholders on all three sets of criteria.

\subsection{Marketing and Poverty}

One of the big challenges of the $21^{\text {st }}$ century will be to deal with the world poverty issue. Some 4 billion people - approximately two-thirds of the world population - live on less than 1000 dollars a year. They outnumber the rich - or at least those earning $\$ 10000$ or more a year - by a factor of 8 to 1 . It is today a wellestablished fact that economic growth of a country is closely correlated to the 
creation of new enterprises of this country. Thus, entrepreneurship can be a powerful mean to reduce poverty.

As observed in the field of finance where the development of micro-credit have contributed in a significant way to facilitate entrepreneurship in poor countries, shouldn't we - marketing scholars and marketing professionals - also develop forms of low-cost or low-frills marketing - both in strategic and operational marketing - to give poor countries entrepreneurs appropriate marketing instruments? Some companies are now deliberately targeting the poor by adopting strategies like the following (Arthur D. Little, 2003):

1. reformulating consumer goods being sold in much smaller packages, thus making them affordable for the poor (selling jeans in ready-to-assemble packs);

2. trying to cut transaction costs by introducing more appropriate distribution systems that link old and new technologies (bicycles and mobile phones);

3. adopting technologies to make products more affordable and socially beneficial, like solar cells to generate electricity in low-income communities;

4. reducing prices of the good or waive any profits in order to help the poor and the disadvantages. This issue is hotly debated today in the pharmaceutical sector.

Thus, it seems that Business, and in particular marketing, have a role to play in selling more to the poor. It can be profitable for the companies involved and it can help to improve the quality of life of the poor. If making profits from poverty may make good financial sense, is it ethically acceptable? The argument goes like this: if those who are currently excluded from consumer society are not brought into the economy, the divide between rich and poor will widen further, creating more social tension and undermining future development.

\section{Conclusions}

Within the globalised economy, strategic marketing has a more important social role than it ever had. It remains the best mechanism to adjust demand to supply, but it also triggers a virtuous circle of economic and social development, reinforced today by the social, cultural and technological changes observed in the market. These evolutions in the interconnected global economy create grounds for optimism in that they are contributing to a more democratic and transparent market economy, based on new values. In this new environment, national and supranational authorities have a key role to play: to monitor and to control the initiatives taken to meet emerging needs in order to reconcile market efficiency with the imperatives of a social vision.

\section{Bibliography}

Arthur D.Little, The Ethics of Making Money from the Poor, ADL Environment and Risk Discusion Forum, 2002.

Berquier-Ghérold V., De l'infomédiaire au portail communautaire : restructuration des marchés et protection de la vie privée, La protection de la vie privée dans la société d'information, Paris Presses Universtaires de France, 2000. 
Brender A., L'impératif de solidarité, Paris, Editions La Découverte, 1996.

Charitou C.D., Markidès C.C., Responses to Disruptive Strategic Innovations, MIT Sloan Management Review, 2003, pp. 55-63.

De Woot Ph., The responsible Corporation, Working paper, Louvain-la-Neuve, 2002.

Drucker P., Can e-commerce deliver?, The World in 2000, The Economist, 2000, p.122.

Gladstone J.A., Scheibal W.J., Privacy on the internet: Europe and the US converge, European Business Forum, n. 5, Spring, 2001.

Lambin J.J., Market-Driven Management, Strategic and Operational Marketing, London, Macmillan Business, 2000. (See also, Le marketing stratégique: du marketing à l'orientationmarché, Paris, Dunod, $5^{\text {ième }}$ édition, 2002).

Laudicina P.A., The Globalization Ledger, Executive Agenda, vol. 3, n. 1, 2000, pp. 61-69, une publication de A.T. Kearny.

Ghemawat P., Distance Still Matters: The Hard Reality of Global Expansion, Harvard Business Review, September, 2001.

Sawhney M., The Death of Friction, Round Table Group, 1997. 